\title{
Renewing Social Democracy by Re-mobilising the Working Class?
}

\begin{abstract}
This chapter concludes by summarising the main results of the book. It closes with a discussion on the renewal of social democracy and reviews current proposals and experiences. With this aim, it evaluates the role of the working class in social democracy's future electoral strategies. It discusses the risks for social democracy in abandoning the workers' vote and examines some factors that would facilitate the electoral mobilisation of workers in the future. Based on current debates on the future of social democracy, it then reviews possible ideological reorientations of social democracy and evaluates their chances of success among its (potential) supporters.
\end{abstract}

Keywords Social democracy · Electoral strategies · Trade unions · Service workers · Mobilisation · Immigration

\section{Fragmentation IN THE Working-Class \\ VOTE AND THE DE-PROLETARIANISATION OF SOCIAL DEMOCRACY}

The empirical analyses conducted in Chapters 3 and 4 examined the class basis of social democratic parties at two different time points, the first one in the 1970s and the second one in the 2010s. The two time

(C) The Author(s) 2020 89

L. Rennwald, Social Democratic Parties and the Working Class, Challenges to Democracy in the 21 st Century, https://doi.org/10.1007/978-3-030-46239-0_6 
points are representative of two different periods for social democracy, one in which social democracy achieved strong electoral successes and one in which it suffered electoral defeats. The book has shown how the relationship between social democratic parties and their working-class constituency has strongly changed between the two periods. The analysis on the 1970s conducted in Chapter 3 showed the existence of a relatively strong proximity between production workers and social democratic parties in electoral contests. Production workers voted clearly more than average for social democratic parties and they represented a large share of their electorate. In Chapter 4 , all the indicators pointed towards a decomposition of this specific relationship. In the 2010s, production workers were much less distinctive in their support for social democracy and they clearly represented a smaller share of its electorate. Moreover, production workers were much more likely to abstain from voting in the 2010s. Importantly, the transformation of social democracy's relationship with the working class was not only a question of structural change with workers representing a smaller share of the total electorate. The effect of structural change on social democracy was clearly reinforced by a weakening support on the part of workers.

As a result, the working-class vote has become more complex and above all more fragmented. While they enjoyed some kind of monopoly over the working-class vote in the 1970s, social democratic parties now face competition on multiple fronts. One cannot reduce the new voting patterns to a choice between social democratic and radical right parties, as is often suggested in public discourse. Abstention is nowadays a fundamental characteristic of working-class voting behaviour. The decision for workers nowadays is not only a choice between different parties but first and foremost a choice between abstention and voting. Then, social democracy competes with both the radical left and the radical right, while mainstream right parties also capture an important share of the workingclass vote. However, workers are not more likely than the average voter to support the mainstream right, while the opposite is clearly the case for radical left and radical right parties. The contest from the left of social democracy for the workers' vote is not something new. However, the presence of challengers to the left of social democracy has expanded in several countries in recent decades. Among the countries studied, only the French party system in the 1970s was distinctive in this respect, with a relatively strong Communist Party. In the 2010s, next to France, radical left parties in Germany and the Netherlands also attracted some shares of 
the workers' vote. Moreover, competition from the centre or the right for the working-class vote is also not really new. However, the rivalry has significantly expanded to more countries. In the 1970s, Christian Democratic parties constituted sizeable challengers for the working-class vote in just a few countries. Nowadays, the capture of working-class vote shares by radical right parties concerns all countries. Hence, social democracy only faced competition for the working-class vote in specific contexts in the 1970s but nowadays fighting on multiple fronts represents the normal case for it.

The consequence of the new voting patterns is clearly a weakening of the status of social democracy as working-class parties. However, the book has conceived the trajectory of social democracy in a more refined way than previous research. First, as Chapter 3 showed, even if there was a strong connexion between workers and social democracy, it would be wrong to understand social democracy in the 1970s as a purely working-class movement. Instead of conceptualising social democratic parties as 'pure working-class parties', the book has shown that social democratic parties are closer to the ideal type of 'hybrid workingclass parties', with a strong mobilisation of production workers co-existing with an intermediate mobilisation of lower white-collar workers. Second, as was discussed in Chapter 4, it would be imprecise to characterise social democratic/socialist/labour parties in the 2010 s as parties of the (new) middle classes. In many countries, social democratic parties are closer to cross-class parties, where no social class presents a particularly high level of support and where the composition of their electorate mirrors the composition of the eligible population. Hence, instead of emphasising a shift from the working class to the middle class, the trajectory implies a transformation from hybrid working-class parties to cross-class parties.

Examination of the changing voting patterns has also revealed strong cross-national variation. In countries where the class cleavage was more dominant and no serious competitor for the working-class vote was present, the mobilisation of workers was more important in the 1970s than in countries with competition for the working-class vote. One can observe that social democracy/labour in Austria and Great Britain mobilised the working-class vote the most and relied less on other classes in the 1970s, while in Germany, the Netherlands and Switzerland, the mobilisation was less strong and social democracy relied more on other classes. France was clearly an exception, with a strong cross-class profile of the French Socialist Party's electorate, and the party faced competition 
from the Communist Party. There is important path dependency in the working-class mobilisation of social democracy. In countries that relied more heavily on the working-class vote, the demobilisation of workers led them to become more clearly cross-class parties in the 2010s. In countries that already relied more on the vote from other segments, there was a higher proximity to the ideal type of new class parties in the 2010s. There was again some opposition between Austria and Great Britain on the one hand, and Switzerland and the Netherlands on the other hand.

Historically smaller social democratic parties have therefore followed a different path than historically larger social democratic parties. They have regenerated their electorate - either strategically or unintentionallyby turning more explicitly to the new middle classes, which were already closer to social democracy. It is also no coincidence that the structure of the electorate is less predominantly working class in these countries. To some extent, social democratic parties have been responsive to the structure of the electorate. However, this does not mean that they have been more successful at the ballot box. In the 1970s, the Swiss Social Democratic Party received almost $25 \%$ of the vote, but in the 2010 s it did not achieve more than $19 \%$ (and even reached a historical low of $16.8 \%$ in the 2019 election). The scores of the Dutch Labour Party oscillated between a quarter and a third of the votes in the 1970s decade. In the 2010s, it never reached more than a quarter of the vote (with a disastrous score of $5.7 \%$ in 2017). This suggests that there is not a winning formula whereby 'new class parties' find an easier way to electoral success than 'cross-class parties'. This suggests that the remedies are different from one case to the next. Importantly, one should take this cross-national variation into account when one thinks about the potential ways for social democracy to renew its electoral success. The composition of the electorate can be relatively different from one case to the next, and renewing the confidence of the working class does not mean the same (and does not have the same implications) in each context.

\section{Continuity in Preferences; Changes in Parties' Political Offers}

Chapter 5 examined possible explanations of the growing distance between workers and social democratic/labour parties. It contrasted explanations that focus on the demand side of politics with ones that concentrate on the supply side. On the one hand, it investigated the 
political attitudes of workers and social classes; on the other hand, it considered major trends in parties' political projects in recent decades. The results suggest that changes in the way parties mobilise their electorates are more important than changes in workers' political attitudes. Transformations in parties' political offers have produced a smaller likelihood of workers being mobilised on the basis of their social class, and by extension, a greater likelihood of them being mobilised on competing cleavages. Social democratic parties have contributed to a demobilisation of social class by revising their original political project and adopting a more friendly position towards the market in most European countries. They also responded to societal demands in the domain of cultural liberalism in the aftermath of the post-1968 social movements. This contributed again to mobilising other identities, for example gender, but not social class in a strict sense. Meanwhile, other actors have entered the political arena and sought to mobilise workers on the basis of competing identities. This is particularly the case of radical right parties, which have put forward an anti-immigration agenda aimed at creating new divisions among workers based on nationality. This political agenda stands, therefore, in strong contrast to the idea of international class solidarity that is historically at the core of the labour movement.

Examination of workers' and social classes' political attitudes has shown a pattern of stability over time, at least in comparison with what can be considered a major reversal in the way parties appeal to social classes or other identities. First, on socio-economic issues, workers have consistently demanded more redistribution than the average respondent, both in the 1970 s and in the 2010s. Although the differences between classes are not always very strong, there is a clear class pattern with (production or service) workers being more in favour of redistribution and managers being less in favour of redistribution. This continuity in the preferences of workers suggests that a lower position in the social structure translates more or less directly into a demand for redistribution. However, one must also notice the pro-redistributive attitudes of socio-cultural professionals. Being a member of the salaried middle classes (and hence being located in a higher position in the social structure in comparison with workers) does not imply by definition an opposition to redistribution. Instead, the results indicate divisions within the broad category of the salaried middle classes. This also suggests a real potential to develop new coalitions between workers and segments of the salaried middle classes on redistribution issues. 
Second, on socio-cultural issues, workers display a more critical stance towards immigration than the salaried middle classes. The results on the Swiss case, where immigration was strongly debated in the arena of direct democracy in the 1970s, indicate a strong continuity in the sceptical stance of workers towards immigration. Interestingly, anti-immigration positions (in the arena of direct democracy) were compatible with support for social democracy (in the electoral arena) at the time in this country. The results for the other countries indicate that workers have become more sceptical towards immigration over time. However, one should remain cautious about this finding, given that the questions available referred more to the integration of migrants in the 1970s and less to a general evaluation of migration, as in the 2010s.

Overall, our results suggest that the ways parties have transformed their political projects (and therefore their appeals to the different preferences of workers and social classes) are important to understand changes in voting patterns. Analysis of political attitudes indicates that demands from social classes display a strong continuity over time. The preferences of workers still tilt towards social democratic policies in the socio-economic realm. However, social democracy has been less concerned with the goal of redistribution in recent decades. Moreover, the preferences of workers tilt towards the agenda of radical right parties in the domain of immigration policies. Given the high salience of migration issues in contemporary politics, social democratic parties objectively face more difficulties in mobilising workers on the socio-economic dimension-independently of their own transformations on these issues.

After having presented the main results of this book, the rest of this conclusion turns to possible attempts to re-mobilise the working class for a social democratic project. It also reviews different ideological reorientations and their effects on working-class mobilisation. More generally, the rest of the conclusion questions the future of social democracy and the different paths it can choose.

\section{Should Workers Be Mobilised at All?}

Disagreements about social democracy's future electoral strategies often concern the emphasis that should be placed on the (re-)mobilisation of the working-class vote. Based on the observed transformation of its voters' class composition, it may be tempting to argue that regaining the working-class vote is not a worthwhile project for social democracy. In 
this perspective, winning again the workers' vote is a task too difficult, and above all is not likely to contribute decisively to social democracy's vote share. A better strategy would therefore be to concentrate efforts fully on the new middle classes, which represent growing segments of the electorate. From this point of view, the advantage would also be in avoiding dilemmas that originate from the divergent preferences of social democracy's electorate on socio-cultural issues (e.g. on immigration, as was shown in Chapter 5). Giving priority to mobilising the new middle classes, which have a (uniform) liberal position on cultural issues, eliminates the difficulties for social democracy in finding policy positions that are suitable for different constituencies.

The book has demonstrated, however, the continuing importance of the working class-if one is willing to enlarge its contours. This presupposes a disposition to observe transformations in political economies and to adjust the representation of the working class to occupations such as shop assistants, hairdressers and delivery drivers. Clearly, production workers have become a smaller segment of the population entitled to vote, but if one defines both production and service workers as being part of the working class, the picture changes dramatically. The enlarged working class represents a noticeable share of the entire electorate. As was shown in Chapter 4 of this book, the enlarged working class represents between 40 and $45 \%$ of the entire electorate in three countries in our sample (Austria, France and Great Britain) and between 30 and 35\% in three other countries (Germany, the Netherlands and Switzerland). It is only in these latter countries that the new middle classes represent a larger proportion of the eligible electorate.

Of course, the new service proletariat represents a difficult constituency to mobilise. Social democratic parties can rely less on trade union allies to reach this electoral segment. It must be remembered here that union members are more likely to take part in elections (e.g. Flavin and Radcliff 2011 ) and when then do they are more likely to support left-wing parties (e.g. Arndt and Rennwald 2016; Mosimann et al. 2019). Union density in low-end private services remains lower than in the manufacturing sector in advanced industrial countries at the end of the 2010s (Pontusson 2013: 802-803). On average, service workers are active in establishments of smaller size and there is a large diffusion of atypical employment. These two factors are strongly associated with a lower propensity to unionise (Pontusson 2013). Isolation at work, which is widespread among certain 
categories of service workers (e.g. in cleaning or security), also depresses electoral participation (Peugny 2015).

Among production workers, the prospects are also bleak with respect to unionisation. In the same study, Pontusson observes significant declines in the manufacturing sector in almost all countries from the 1980s to the end of the 2000s. These relate to the decentralisation of production and the spread of atypical employment in manufacturing (2013: 802-803). This explains partly, at least, why social democratic parties nowadays face more problems in mobilising their traditional constituencies.

A look at history is probably useful here. We may be too much informed by the decades following the Second World War, when the organisations of the labour movement were relatively powerful and when it was relatively easy or normal to mobilise workers. The comparison should instead switch to the turn of the nineteenth century, a time in which labour movement organisations were in their early days, and workers were hesitant about socialist ideas and divided across skills and origins. It was therefore one of the main achievements of the labour movement to develop some degree of unity and class awareness among very diverse segments of the workforce through the diffusion of socialist ideas and the development of a broad network of organisations (see Moschonas 2002: 28-30; Sassoon 1996: 7-8). In recent years, new attempts to forge unity among the fragmented working class can be observed, reminding us of the early days of the labour movement. Trade unions have intensified their efforts to organise the new service proletariat and, more generally, to become more inclusive towards workers with atypical employment contracts (e.g. Benassi and Vlandas 2016; Doellgast et al. 2018, Rathgeb 2018; Rieger et al. 2012). However, these new attempts to forge unity will require numerous years of work-a calendar that is different to that of party strategists focusing on maximising vote shares in a brief period of time.

\section{How Should Workers Be Mobilised?}

As Cas Mudde (2019) emphasises, several politicians and leaders from social democratic parties have advocated for stricter immigration policies when their parties have been confronted with electoral decline. The reason that is invoked is often similar from one social democratic party to the next. As Mudde explains, social democratic parties perceive the loss of the working class to the radical right as the main cause of their 
electoral decline, and the remedy is a defence of a more restrictive immigration agenda. However, this book has clearly demonstrated that voting for radical right parties represents only one option among others for workers in contemporary politics. Hence, as Mudde argues in the same article, it would be wrong to assume that the electoral rise of radical right parties is caused by working-class voters abandoning social democratic parties. The book has shown an important diversity in the new voting choices of workers - and therefore an important fragmentation of the working-class vote. Of course, a significant de-proletarianisation of the electorate for social democracy has occured. Simultaneously, there is an undeniable process of proletarianisation of the electorate for the radical right. However, other transformations have been underlined. First and foremost, there is a large proletarianisation of the group of abstainers. Second, radical left parties and, to some extent, mainstream right parties also attract shares of the working-class vote.

Interestingly, when considering how to re-capture the working-class vote, being tougher on immigration is often represented as the only solution by pundits or politicians from social democracy. Such a position goes hand in hand with the flourishing of stereotypes about the working class and the growing association of it in public discourse with a group of angry and uneducated citizens. It is interesting to note that aspirations for redistribution-in Chapter 5 we observed the support for redistribution among workers-are entirely absent from the discussions. In this respect, it appears necessary to reframe the terms of the debate. One must remember the broader transformation of social democracy on socioeconomic issues with extensive revisions of its political project. One must also remember that social democracy was always more liberal on the sociocultural dimension than Conservatives, Christian Democrats and even mainstream liberal parties. Even if one focuses on the position of social democracy on cultural liberalism and immigration, one should not forget the transformation at the core of social democracy's political project. This means on issues related to the role of the state in the economy and redistribution. If the traditional functions of social democracy on the socio-economic dimension are neglected, it becomes difficult to convince voters to support this party family on the basis of cultural issues. Isolating the cultural positions of social democracy from its economic positions therefore misses an essential part of the story.

Having made this clarification, one must nonetheless observe that issues related to immigration and European integration represent an 
important challenge for social democracy-and generally for mainstream parties (e.g. Hooghe and Marks 2018), especially when they are very salient on the political agenda. One must therefore think about the best ways for social democracy to face the saliency of these issues. In an article published in 2010, Tim Bale and other co-authors (Bale et al. 2010) discussed several options for social democratic parties when they are confronted with the rise of radical right parties in the policy domain of immigration. They can try to stick to a strong pro-immigrant view, they can try to advocate stricter immigration policies, or they can try to avoid the issue of immigration and contribute to decreasing the salience of immigration overall. The last two options have been the most discussed and (partially) implemented by social democratic parties in recent years.

Adopting a stricter immigration policy poses several problems for social democracy. First, it is in contrast to the ideological core of social democracy based on internationalism and class solidarity. A move towards the defence of the 'white' working class would represent an enormous shift in the history of the labour movement - of similar magnitude to the thirdway turn of social democracy. Second, this would pose some electoral problems. Advocating more restrictive policies would contain the risk of alienating segments of the middle classes that are in favour of proimmigration policies (see Abou-Chadi and Wagner 2020). Moreover, one should also not forget that the working class often has a migration background-reducing the working class to the white working class would therefore be an important mistake.

Among the various social democratic parties (or leaders) in Europe that have either considered or endorsed a stricter position on immigration (see Mudde 2019), the Danish Social Democrats campaigned the most explicitly on an anti-migration position in the recent 2019 election, following a new paper adopted in 2018 (see Nedergaard 2018). The Social Democrats led by Mette Frederiksen were the clear winners of this election and returned to office with a minority government. The harsh line defended by the party on immigration was prominently discussed in the media as a major reason for its electoral success. However, there are two reasons to remain cautious about Danish Social Democracy being a new model for its sister parties. First, the Social Democrats did not achieve a particularly high vote share-instead they slightly dropped from $26.3 \%$ in the last election to $25.9 \% .{ }^{\text {l }}$ Second, it is difficult to isolate the effect of migration, since the Social Democrats under the new leadership also kept 
their distance from the third way and emphasised a more classical social democratic agenda on socio-economic issues (e.g. Møller Stahl 2019).

Another strategy could be to avoid talking about immigration (this could also apply to European integration) and instead increase the saliency of socio-economic issues. This strategy clearly speaks to the commonalities of workers and segments of the salaried middle classes on redistributive issues, as was shown in Chapter 5 of this book. In contrast, these groups have more diverging preferences on immigration issues. It is therefore relatively wise to concentrate party statements on issues where there is agreement between the diverse segments of the (potential) electoral base and to try to decrease the attention on issues where there is a strong disagreement. To some extent, this was the strategy adopted by Jeremy Corbyn after the 2016 Brexit referendum. Given the divergent positions on Brexit within the Labour Party voter base, it was logical to focus attention on issues where constituencies share similar views. Moreover, Corbyn's project was to reorient the Labour Party towards a more classical left-wing economic policy agenda. Hence, giving priority to the fight against austerity and the rebuilding of the National Health Service over discussions about Britain's relationship with the EU appeared relatively consequential from this point of view. When Brexit was not at the centre of the electoral campaign, as was the case in 2017, this strategy offered Labour a relatively high score $(40 \%$ of the vote share, the highest score since the 2001 general election). However, when Brexit dominated the electoral campaign and was in the mind of many voters, as was the case in 2019 , the approach led to a strong Labour defeat, above all in terms of seats-the weakest score since 1935. Hence, such a strategy is relatively risky and its success depends on the capacity of social democracy to focus the attention in the entire electoral campaign on economic issues.

None of these solutions therefore appear ideal for social democracy. One should therefore think whether the future of social democracy is closely connected to another option: integrating the economic and cultural dimensions better in its political project. Instead of emphasising socio-economic issues to the detriment of socio-cultural issues, instead of a strong disentanglement of the two dimensions, the most important task for social democracy would be to better show how the two are strongly connected. This would allow the different preferences of its heterogeneous electorate to be respected. Hence, to some extent, Social Democrats need to reframe the new cultural issues in their own ideology. They must therefore propose a socio-economic translation of 
cultural problems, as the radical right has been able to offer a sociocultural translation of economic conflict in recent decades. In doing so, social democracy can aim to again fulfil its historical role of integrating the working class into democratic politics and hence to increase its representation in the party system overall.

\section{Note}

1. They could count on important gains by the Danish Social Liberal Party and the Socialist People's Party to receive support for their minority government.

\section{REFERENCES}

Abou-Chadi, T., \& Wagner, M. (2020). Electoral Fortunes of Social Democratic Parties: Do Second Dimension Positions Matter? Journal of European Public Policy, 27(2), 246-272.

Arndt, C., \& Rennwald, L. (2016). Union Members at the Polls in Diverse Trade Union Landscapes. European Journal of Political Research, 55(4), 702-722.

Bale, T., Green-Pedersen, C., Krouwel, A., Luther, K. R., \& Sitter, N. (2010). If You Can't Beat Them, Join Them? Explaining Social Democratic Responses to the Challenge from the Populist Radical Right in Western Europe. Political Studies, 58(3), 410-426.

Benassi, C., \& Vlandas, T. (2016). Union Inclusiveness and Temporary Agency Workers: The Role of Power Resources and Union Ideology. European Journal of Industrial Relations, 22(1), 5-22.

Doellgast, V., Lillie, N., \& Pulignano, V. (2018). Reconstructing Solidarity: Labour Unions, Precarious Work, and the Politics of Institutional Change in Europe. Oxford: Oxford University Press.

Flavin, P., \& Radcliff, B. (2011). Labor Union Membership and Voting across Nations. Electoral Studies, 30(4), 633-641.

Hooghe, L., \& Marks, G. (2018). Cleavage Theory Meets Europe's Crises: Lipset, Rokkan, and the Transnational cleavage. Journal of European Public Policy, 25(1), 109-135.

Møller Stahl, R. (2019, May 6). Selling Out Our Values, Jacobin. https://www. jacobinmag.com/2019/06/denmark-elections-social-democrats-immigration.

Moschonas, G. (2002). In the Name of Social Democracy: The Great Transformation, 1945 to the Present. London: Verso.

Mosimann, N., Rennwald, L., \& Zimmermann, A. (2019). The Radical Right, the Labour Movement and the Competition for the Workers' Vote. Economic and Industrial Democracy, 40(1), 65-90. 
Mudde, C. (2019, May 14). When Copying the Populist Right Isn't Going to Save the Left. The Guardian. https://www.theguardian.com/news/2019/ may/14/why-copying-the-populist-right-isnt-going-to-save-the-left.

Nedergaard, P. (2018). Back to Its Roots: Why Do the Danish Social Democrats Want a More Restrictive Immigration Policy? Budapest: Friedrich-EbertStiftung Regional Project "Flight, Migration, Integration in Europe". http:// library.fes.de/pdf-files/bueros/budapest/14498.pdf.

Peugny, C. (2015). Pour une prise en compte des clivages au sein des classes populaires. La participation politique des ouvriers et des employés. Revue Française De Science Politique, 65(5-6), 735-759.

Pontusson, J. (2013). Unionization, Inequality and Redistribution. British Journal of Industrial Relations, 51(4), 797-825.

Rathgeb, P. (2018). Strong Governments, Precarious Workers: Labour Market Policy-Making in the Era of Liberalisation. Ithaca, NY: Cornell University Press.

Rieger, A., Pfister, P., \& Alleva, V. (2012). Verkannte Arbeit. Dienstleistungsangestellte in der Schweiz. Zurich: Rotpunktverlag.

Sassoon, D. (1996). One Hundred Years of Socialism: The West European Left in the Twentieth Century. London: Tauris.

Open Access This chapter is licensed under the terms of the Creative Commons Attribution 4.0 International License (http://creativecommons.org/licenses/ by $/ 4.0 /)$, which permits use, sharing, adaptation, distribution and reproduction in any medium or format, as long as you give appropriate credit to the original author(s) and the source, provide a link to the Creative Commons license and indicate if changes were made.

The images or other third party material in this chapter are included in the chapter's Creative Commons license, unless indicated otherwise in a credit line to the material. If material is not included in the chapter's Creative Commons license and your intended use is not permitted by statutory regulation or exceeds the permitted use, you will need to obtain permission directly from the copyright holder.

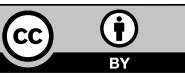

